\title{
1,5-Anhydro-D-Fructose and its Derivatives: Biosynthesis, Preparation and Potential Medical Applications*
}

Authors

Affiliations
Roland Fiskesund ${ }^{1}$, Kazuhiro Abeyama ${ }^{2,3}$, Kazuhiro Yoshinaga ${ }^{4}$, Jun-ichi Abe $^{5}$, Yongbing Yuan ${ }^{6}$, Shukun $\mathrm{Yu}^{7}$

The affiliations are listed at the end of the article
Key words

- 1,5-anhydro-D-fructose

- anhydrofructose pathway

- anticancer activity

- diabetes

- inflammation

- dental care

- morels

- red algae received May 9, 2010

revised June 5,2010

accepted June 14, 2010

\section{Bibliography}

Dol http://dx.doi.org/

10.1055/s-0030-1250120

Published online July 19, 2010

Planta Med 2010; 76:

1635-1641 @ Georg Thieme

Verlag KG Stuttgart · New York

ISSN 0032-0943

\section{Correspondence}

Roland Fiskesund, MD

Department of Medicine Unit of Emergency Medicine Karolinska Institute, Huddinge SE-171 77 Stockholm

Sweden

Phone: +46702650477

roland.fiskesund@ki.se

\section{Abstract}

$\nabla$

1,5-Anhydro-D-fructose (AF) was first found in fungi and red algae. It is produced by the degradation of glycogen, starch and maltosaccharides with $\alpha$-1,4-glucan lyase (EC 4.2.2.13). In vivo, AF is metabolized to 1,5-anhydro-D-glucitol (AG), ascopyrone P (APP), microthecin and other derivatives via the anhydrofructose pathway. The genes coding for the enzymes in this pathway have been cloned, enabling the large-scale production of AF and related products in a cell-free reactor. The possible applications of these products in medicine have been evaluated using both in vitro and in vivo systems. Thus AF is a useful anticariogenic agent as it inhibits the growth of the oral pathogen Streptococcus mutans, impairing the production of plaque-forming polysaccharides and lactic acid. AF also shows anti-inflammatory and anticancer effects. AG is used as a diabetic marker for glycemic control. AG also stimulates insulin secretion in insulinoma cell lines. In vivo, APP has been

\section{Introduction}

$\nabla$

Despite advances in modern medicine assisted by structural biology and bioinformatics, naturally derived products and their derivatives still represent an important part of our arsenal in maintaining health and well-being. This is because although many active substances are available in the vastly diverse biological systems, their uses are restricted as they usually occur in low amounts. Additionally, lengthy or unknown biosynthetic pathways have made metabolic engineering difficult either in the organism producing the active products or in microbes with character-

\footnotetext{
* Dedication

Dedicated to Professor Inge Lundt, Department of Chemistry, Technical University of Denmark
}

shown to lengthen the life span of cancer-afflicted mice. It interferes with tumor growth and metastasis by its cidal effects on fast multiplying cells. Microthecin inhibits the growth of the human pathogen Pseudomonas aeruginosa PAO1, particularly under anaerobic conditions. The pharmaceutical usefulness of the other AF metabolites 1,5-anhydro-D-mannitol,1-deoxymannojirimycin, haliclonol, 5-epipentenomycin I, bissetone, palythazine, isopalythazine, and clavulazine remains to be investigated. In this review AF and its metabolites as the bioactive natural products for their pharmaceutical potentials are discussed.

\section{Abbreviations \\ $\nabla$ \\ AF: $\quad$ 1,5-anhydro-D-fructose, 1,5-anhydro-D-arabino-hex-2-ulose \\ AG: $\quad$ 1,5-anhydro-D-glucitol \\ APP: $\quad$ ascopyrone P, 1,5-anhydro-4- deoxy-D-glycero-hex-1-en-3-ulose}

ized genetic background. It is also known that many secondary metabolites are derived from various precursors, such as amino acids whose synthesis is tightly regulated. Furthermore, organisms that produce these active substances may not be cultivable.

In contrast to known secondary metabolic pathways [1], the anhydrofructose pathway is unique in two aspects ( Fig. 1) [2,3]. For the first, the precursors of AF are glycogen and starch, which as the carbon and energy storage molecules in cells usually occur in large quantities; for the second, this pathway involves only a limited number of well-characterized enzymes and genes. This makes the in vitro biocatalytic production of these metabolites in large quantities possible $[4,5]$. In the last two decades, studies on AF biogenesis and its metabolism have been mainly performed 
in EU laboratories [2,3], while studies to explore the medical applications of AF have largely been carried out by some laboratories in Japan [6-9]. These works have been published in various forms and different languages. The purposes of this review are to summarize and critically evaluate the achievements made in this area with an emphasis on the roles of AF and its metabolites including chemical derivatives in health care. Future developments that could further research in this area and perspectives that could lead to additional uses of these products in health care are discussed.

\section{Occurrence and Biosynthesis of AF and its Derivatives: The Anhydrofructose Pathway \\ $\nabla$}

The biological occurrence of AF was first reported in morels in 1987 [10]. It is produced by the degradation of $\alpha-1,4$-glucans including glycogen, starch and maltosaccharides catalyzed by $\alpha$ 1,4-glucan lyase (EC 4.2.2.13) ( $\bullet$ Fig. 1) [11,12]. As can be seen from $\odot$ Fig. 1, via the anhydrofructose pathway, AF is metabolized in vivo to 1,5-anhydro-D-glucitol (AG), ascopyrone P (APP), microthecin and other metabolites. Today it is known that AF or the AF-forming glucan lyase occurs in bacteria, fungi, algae and mammalian tissues ( 0 Table 1) [13-20]. For detailed treatment of this pathway the readers are referred to recent reviews $[2,3]$.

\section{Enzymatic and chemical preparation of AF and its derivatives}

The preparation of AF, APP and microthecin can be achieved from inexpensive and renewable materials such as starch in one pot since none of the enzymes for their synthesis such as glucan lyase, dehydratases and tautomerase need any cofactors $[2,3]$. Thus laboratory-scale production of AF in kilogram quantities has been achieved $[4,21]$. Although inferior to the enzymatic method, AF can also be prepared chemically and recently more efficient methods for the chemical synthesis of AF have been reported $[22,23]$. APP can also be prepared by chemical synthesis from AF [24], or simply by autoclaving AF followed by chromatographic separation [6]. This is why some trace amount of APP is

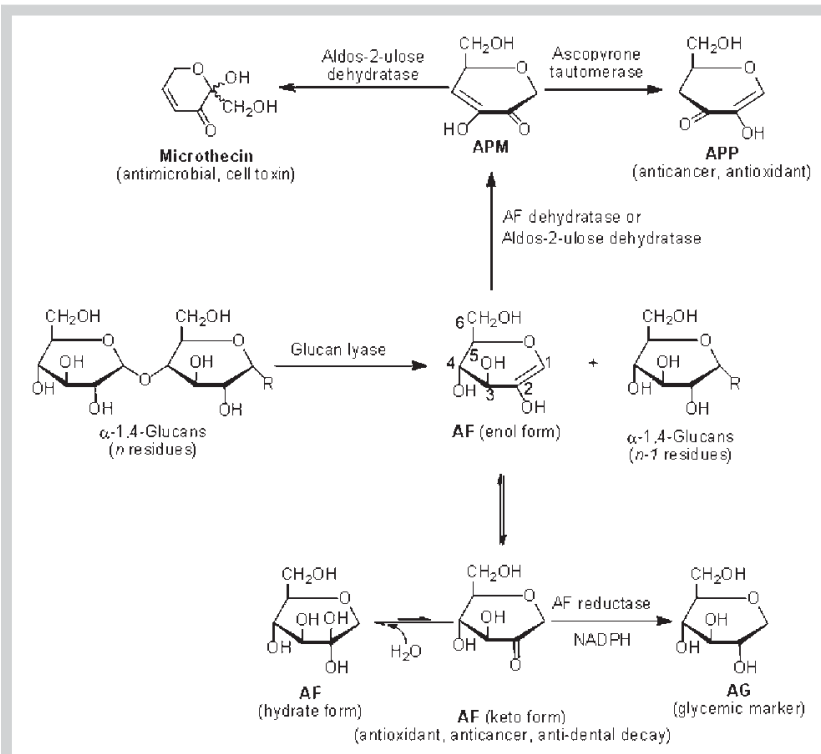

Fig. 1 The formation of AG, APP, and microthecin from $\alpha$-1,4-glucans including glycogen via AF and ascopyrone M (APM) by $\alpha-1,4$-glucan lyase. $\mathrm{AF}$ reductases, $\mathrm{AF}$ dehydratase, aldos-2-ulose dehydratase, and ascopyrone tautomerase are the known enzymes of the anhydrofructose pathway $[2,3]$. The applications including potential applications of these metabolites in medicine are indicated.

found in toasted and fried foods [6]. AG and its stereoisomer 1,5anhydro-D-mannitol (AM, syn.: styracitol) can be produced from $\mathrm{AF}$ by the action of $\mathrm{AF}$ reductases $[2,3,25]$. AG and AM can also be prepared chemically by stereoselective reduction of $\mathrm{AF}$ at $\mathrm{C}-2$ with the aid of suitable catalysts and reducing agents [26].

$\mathrm{AF}$ has been shown to be a versatile precursor for the synthesis of a variety of AF derivatives. These include a variety of naturally occurring metabolites, such as 1-deoxymannojirimycin [27], haliclonol [28], 5-epipentenomycin I [29], bissetone [30,31], palythazine, isopalythazine, and clavulazine $[23,30]$. For a discussion on their syntheses the readers are referred to the recent review [23].

Table 1 Occurrence of 1,5-anhydro-D-fructose (AF) and $\alpha$-1,4-glucan lyase in selected prokaryotic and eukaryotic organisms.

\begin{tabular}{|c|c|c|c|}
\hline Organisms & AF concentration ( $\mu \mathrm{g} / \mathrm{g}$ fresh tissue) & $\alpha-1,4$-Glucan lyase & References \\
\hline $\begin{array}{l}\text { Escherichia coli C600 (Migula) Castellani } \\
\text { et Chalmers }\end{array}$ & $+a$ & $-b$ & [19] \\
\hline Trichodesmium erythraeum Ehrenberg IMS101 & - & + & [3] \\
\hline $\begin{array}{l}\text { Gracilariopsis lemaneiformis (Bory) Dawson, } \\
\text { Acleto et Foldvik }\end{array}$ & $37-1900$ & + & {$[11,19,56]$} \\
\hline Gracilaria verrucosa (Hudson) Papenfuss & - & + & [11] \\
\hline Gracilaria chorda Holmes & - & + & [57] \\
\hline Ceramium gobii Waern & 1.4 & - & [19] \\
\hline $\begin{array}{l}\text { Furcellaria lumbricalis (Hudson) } \\
\text { J. V. Lamouroux }\end{array}$ & 1.7 & - & [19] \\
\hline Cladophora rupestres (Linnaeus) Kützing & 0.31 & - & [19] \\
\hline Pilayella littoralis (Linnaeus) Kjellman & 0.10 & - & [19] \\
\hline Morchella costata (Vent.) Pers. (ATCC 64173 ), & - & + & {$[12,58]$} \\
\hline Morchella vulgaris (Pers.) Boud. (ATCC 64 176), & - & + & {$[12,58]$} \\
\hline Peziza ostracoderma Korf (ATCC 24032) & - & + & [58] \\
\hline $\begin{array}{l}\text { Anthracobia melaloma (Alb. \& Schwein.) } \\
\text { Arnould (CBS 293.54) }\end{array}$ & - & + & [59] \\
\hline Wistar rat liver & 0.43 & - & [18] \\
\hline
\end{tabular}

a Detected or presence; ${ }^{b}$ Not determined 


\section{The Potential Effects of AF and its Derivatives in Medical Applications \\ $\nabla$}

The role of $\mathrm{AF}$ and its derivative $\mathrm{AG}$ in regulating sugar metabolism

The roles of AF and AG in regulating sugar metabolism have been evaluated, either as the root cause, or as a potential treatment in related disorders including diabetes. By structural comparisons, AF (1-deoxy-2-keto-D-glucose) and AG (1-deoxy-D-glucose) are both analogues of glucose, and therefore their roles as substrates or effectors of selected sugar-metabolizing enzymes have been investigated. Thus rat brain hexokinase (EC 2.7.1.1) has been found to be able to phosphorylate both AF and AG with a $K_{m}$ of 0.79 and $0.83 \mathrm{mM}$, respectively [32]. The phosphorylated forms of $A F(A F$ 6-P) and AG (AG 6-P) have been shown to inhibit the phosphorylation of D-glucose by rat brain hexokinase with a $K_{i}$ of 0.07 and $0.04 \mathrm{mM}$, respectively [32]. AG 6-P has also been shown to inhibit the oxidation of glucose [33]. In contrast to rat brain hexokinase, rat liver glucokinase (EC 2.7.1.2) phosphorylated neither AF nor AG. The phosphorylation of glucose by the glucokinase was, however, inhibited by both AF and AG. For instance, AF and AG at $3 \mathrm{mM}$ inhibited the phosphorylation of glucose at $3 \mathrm{mM}$ by 43.5 and $38.7 \%$, respectively [32].

Mutarotase (EC 5.1.3.3) from hog kidney was inhibited by both $\mathrm{AF}$ and AG though at a lesser extent [32]. For instance, at $2 \mathrm{mM}$, $\mathrm{AF}$ and AG inhibited the mutarotation of glucose at $2.3 \mathrm{mM}$ by 16 and $33 \%$, respectively. The mutarotase from hamster intestine was inhibited by AG with a $K_{i}$ similar to its $K_{m}$ for glucose (25 mM) [34]. Like glucose, AG has been reported to inhibit glycogenolysis by inhibiting rat hepatocyte phosphorylase but unlike glucose it did not activate glycogen synthase (EC 2.4.1.11) [35].

The data related to the effects of AF and AG on sugar metabolism at the enzymatic level obtained to date are quite fragmentary. Moreover, the inhibitory effects of $\mathrm{AF}$ and $\mathrm{AG}$ have not been linked to disorders of sugar metabolism. The roles of and the further metabolism of AF 6-P and AG 6-P formed by hexokinase in different mammalian organs and tissues deserves further investigation.

\section{The roles of $\mathrm{AF}$ and its derivative AG in stimulation of insulin secretion}

To further study the possible roles of AF and AG in regulating sugar metabolism and related disorders, especially diabetes, in vitro and in vivo systems including cell cultures, isolated tissues, and rodent models have been used. The results indicate that AF does not seem to play a major role in regulating blood sugar levels either directly or indirectly. This is concluded from the observation that feeding C57BL/6J mice challenged with a high-fat diet at a dose of AF of $30 \mathrm{mg} / \mathrm{mouse} /$ day for 8 weeks did not result in a difference in basal blood glucose and insulin levels between the AFtreated and control groups. Also compared to controls, AF treatment did not affect body weight, food and water intake in the C57BL/6J mice fed with either a high-fat diet or a normal diet (Yu et al., unpublished data).

The role of AG in insulin secretion was examined using isolated rodent islets and cell cultures. Similar to AF, AG at a concentration of 0.05 to $10 \mathrm{mM}$ did not stimulate insulin secretion in isolated islets (Yu et al., unpublished data). In contrast, AG stimulated insulin secretion in two rodent insulinoma cell lines studied, i.e., rat RINr and mouse MIN6 [36]. Insulin release was maximally stimulated to levels 25 and $100 \%$ higher than those of controls (AG-free treatment) in RINr and MIN6, respectively. The effects were con- centration-dependent in the range of 30-610 $\mu \mathrm{M}$, which is within the physiological range of AG concentrations [36]. In addition, at an AG to glucose ratio of $1 / 200$, AG showed an additive effect on insulin secretion with $20 \mathrm{mM}$ glucose. The additive effect was also observed with other types of saccharides and polyols. The secretagogue action of AG was independent of an increase in the intracellular content of cAMP and ATP [36]. These results suggest that AG stimulates insulin secretion through a mechanism that is different from that of glucose. It is known that the MIN6 cell line, which is more sensitive to AG-stimulated insulin secretion, closely resembles normal pancreatic $\beta$-cells in glucose metabolism and glucose-dependent insulin secretion [36]. Studies have shown that pancreatic $\beta$-cells possess a unique AG transport system [37], which may be involved in the effects of AG. Additional studies are needed to have a better understanding on the molecular basis of AG in insulin secretion in insulinoma cell lines, isolated islets and rodent models. AG has been reported to affect the adiponectin concentration in blood positively, which may ameliorate diabetic syndrome [38].

The AF derivative AG as a marker for glycemic control AG is the second most abundant polyol after glucose in human fluid [39]. In Wistar rats, AG has also been detected in brain, liver, pancreas, kidney, spleen, thymus, lung, testis, muscle, and heart tissues at concentrations of $5-15 \mu \mathrm{g} / \mathrm{g}$ fresh tissue [17]. The level of AG in human blood is used as a marker for glycemic control in diabetes patients [40]. Normal serum AG concentration is in the range of 7 to $32 \mu \mathrm{g} / \mathrm{mL}(43-196 \mu \mathrm{M})$ while in patients with noninsulin dependent diabetes mellitus, the AG concentration is reduced to around $2 \mu \mathrm{g} / \mathrm{mL}$ [40]. The differences in the levels occur because AG competes with glucose for reabsorption in the renal tubuli.

\section{AF as an antioxidant}

In neutral to alkaline milieu, AF exhibits good antioxidant properties as a result of the enol function ( $\bullet$ Fig. 1 ) in the AF molecule which can tautomerize to the enediol function between $\mathrm{C}-2$ and C-3, a function also found in ascorbic acid $[41,42]$. The antioxidant activity of AF was first proposed based on its fast reaction with alkaline 3,5-dinitrosalicylic acid reagent at room temperature [43]. Later AF was shown to exhibit antioxidant activity by its scavenging action on 1,1-diphenyl-2-picrylhydrazyl (DPPH) radicals and preventing copper-mediated peroxidation of LDL into proatherogenic oxLDL [41]. When tested with monocytic leukemia cells (THP-1 cells), AF inhibited the formation of reactive oxygen species (ROS) including hydrogen peroxide and superoxide anion induced in the presence of phorbol myristate acetate (PMA) [41]. It has been further demonstrated that AF shows stronger antioxidant activity at physiological $\mathrm{pH}(\mathrm{pH} 7.4)$ than at $\mathrm{pH} 6.5$ and higher efficiency in scavenging superoxide and peroxide generated by THP- 1 cells compared to the nonphysiological DPPH radicals [41]. The antioxidant nature of AF under neutral and alkaline conditions has also been shown in other systems, such as certain food and beverage products including fresh noodles [44], and green tea [42]. When considering its inhibitory effect on lipoprotein oxidation, AF like other antioxidants might play a role in reducing atherosclerosis progression and thereby decrease the incidence of cardiovascular disease [41]. AF has been reported to be safer than fructose [45]. 


\section{AF as an anti-inflammatory agent}

The anti-inflammatory effect of AF was first reported by Abeyama in 2006 [46]. Lipopolysaccharide (LPS) present on the outer membrane of gram-negative bacteria is known to activate immune cells including macrophages and monocytes through a dedicated receptor and initiate inflammation. In tests with cultured mammalian cells and murine models, AF exhibits anti-inflammatory effects by reducing LPS-induced cytokine release [47]. For example, following a challenge with LPS ( $2 \mathrm{mg} / \mathrm{kg}$ body weight) in a murine model, a clear reduction of proinflammatory factors including interleukin (IL)-6 (-57\%), macrophage chemoattractant protein (MCP-1) (-41\%), and tumor necrosis factor (TNF)- $\alpha(-24.6 \%)$ was observed in response to treatment with AF (38.5 mg/kg body weight) compared to control (phosphate buffer saline, PBS). Similar results for the suppression of IL-6, MCP-1, and TNF- $\alpha$ have also been observed in vitro with murine macrophage-like RAW 264.7 cells [47].

The mechanism of AF suppression of cytokine production has been linked to inhibition of LPS-induced NF-KB DNA-binding activity via the suppression of phosphorylation at Ser536 on the p65 subunit of NF-кB [48]. AF also suppresses nuclear translocalization of the NF-KB p65 subunit in LPS-stimulated RAW 264.7 cells. AF has been shown to inhibit LPS-induced nitric oxide (NO) production in the murine macrophage-like cell line RAW 264.7, and to protect mice from LPS-induced lung injury by down-regulating the expression of inducible nitric oxide synthases (iNOS, EC 1.14.13.39) and upregulating the production of IL-10 [48]. In contrast to AF, AG showed an anti-inflammatory effect $[47,48]$.

\section{AF as an antimicrobial and anti-tooth decay agent}

AF has been reported to possess certain antibacterial activities, especially against gram-positive bacteria [7] and particularly anticariogenic activity (Abe et al., unpublished results) [8]. At a concentration of $1 \%$, AF had an inhibitory effect on the growth of Streptococcus mutans Clarke strain GS5 by extending the lag phase to $4-8 \mathrm{~h}$ [8]. Streptococcus mutans is a known significant contributor to tooth decay. AF at $0.5 \%$ in the culture medium suppressed the production of extracellular dextransucrase (EC 2.4.1.5) 20 -fold by S. mutans. More interestingly AF at $0.5 \%$ completely inhibited dextransucrase-catalyzed synthesis of the sticky extracellular polysaccharides which allow the bacteria to cohere on the teeth, forming tooth plaque. $\mathrm{AF}$ at $0.5 \%$ also slowed down the production of lactic acid from fructose by $S$. mutans by a factor of 14 in a culture medium containing $5 \%$ sucrose. Plaque formation and lactic acid buildup contribute to dental decay by causing dental cavities. A future directive would be to elucidate the growth inhibition mechanism, for example, to find out if the effect of $\mathrm{AF}$ is at the enzymatic or gene expression level. Further work to examine the effect of AF on other oral colonizers including Neisseria and other Streptococcus species is needed.

\section{AF and its derivatives APP and microthecin as potential anticancer agents}

AF and its derivatives APP and microthecin were examined for their possible anticancer effects using cell lines and rodent models. AF and APP both show good anticancer effects demonstrated using cell lines and rodent models. APP is apparently more efficient than AF with regard to effective dosages. Microthecin is very effective at killing blood cancer cell lines but on the other hand it also exhibits a cidal effect on normal cell lines. Detailed discussions on these are given below.
For AF, it shows a good anticancer effect in both in vitro cell cultures and in vivo rodent models. AF exhibited an anticancer effect in in vivo studies with C57 BL/6 mice. B16 melanoma cells $\left(5 \times 10^{6}\right.$ cells) were disseminated in the abdominal cavities of the mice followed by daily administration from day two of PBS (control) or AF at a dose level of $200 \mathrm{mg} / \mathrm{kg}$ into the abdominal cavities. The average number of days the mice survived was 19 for those treated with AF and 14 for the controls [9]. In in vitro studies the presence of $\mathrm{AF}(12 \mathrm{mM})$ reduced the number of attached monocytic leukemia (THP-1) cells by 75\% [9]. This suggests that AF interferes with the adherence of THP- 1 cancer cells to the extracellular matrix.

Toxicology studies indicate that $\mathrm{AF}$ is not a mutagen when tested using prokaryotic and eukaryotic cells [49]. AF gave no abnormal symptoms in rodents in acute oral toxicity at $5.0 \mathrm{~g} / \mathrm{kg}$ body weight and 90 -day toxicity studies at $1.0 \mathrm{~g} / \mathrm{kg}$ body weight daily [50].

For APP, its anticancer effect was demonstrated in vitro using various cancer cell lines ( 0 Table 2 ) and in vivo using animal models (O Fig. 2) [9]. Furthermore, it has been shown that the anticancer mechanism of APP is due to its inhibition on cellular DNA synthesis (O Fig. 3) [9].

Table 2 Effect of ascopyrone P (APP) on the mortality of selected cancer cell lines. Cell death was observed $48 \mathrm{~h}$ after APP had been incubated with the cancer cells in cell culture medium containing APP $(1.4 \mathrm{mM})$, FCS $(10 \%)$ at $37^{\circ} \mathrm{C}$ and $5 \%(\mathrm{v} / \mathrm{v}) \mathrm{CO}_{2}$ atmosphere [9].

\begin{tabular}{|l|l|}
\hline Cancer cells & Percentage of dead cells (\%) \\
\hline THP-1 (monocytic leukemia cells) & $33.3 \pm 0.7$ \\
\hline HeLa (human cervical cancer cells) & $8.3 \pm 2.0$ \\
\hline A549 (human lung adenocarcinoma cells) & $48.6 \pm 3.8$ \\
\hline HaCaT (human keratinocyte derived & $27.2 \pm 3.1$ \\
\hline tumor-like cells) & $31.9 \pm 3.6$ \\
\hline $\begin{array}{l}\text { B16 melanoma (C57 BL/6 mouse } \\
\text { melanoma cells) }\end{array}$ & \\
\hline
\end{tabular}

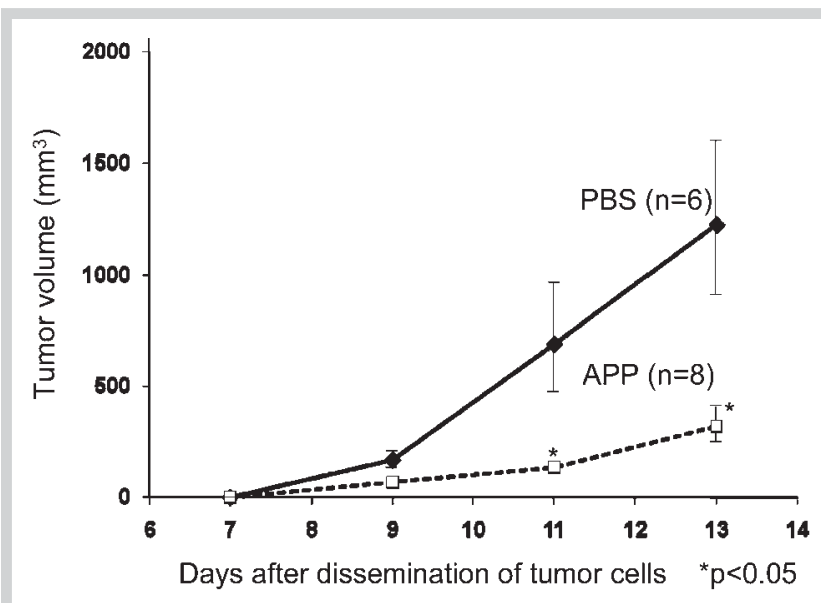

Fig. 2 Effect of APP on tumor growth in terms of tumor tissue volume. APP in phosphate buffer saline (PBS) at a dosage of $25 \mathrm{mg} / \mathrm{kg}$ body weight was subcutaneously injected into the tumor spots in the backs of C57/BL6 mice every other day from the $3^{\text {rd }}$ day to the $13^{\text {th }}$ day [9]. The mice had previously been disseminated with B16 melanoma cells $\left(1 \times 10^{6}\right.$ cells $)$ at day zero. 


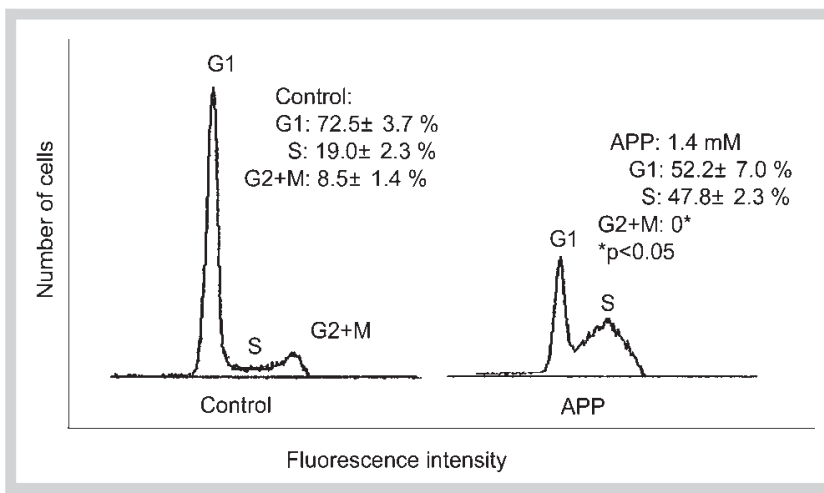

Fig. 3 Evaluation of cell cycle affected by APP as monitored by flow cytometry. HeLa cells were grown in the presence of FCS $10 \%$ with or without the addition of APP ( $1.4 \mathrm{mM}$ ) for $24 \mathrm{~h}$ and examined for cell populations with respect to cell division stages [9].

In in vitro tests, it was observed that the number of B16 melanoma living cells decreased significantly in a concentration-dependent manner in the presence of APP at $7 \mu \mathrm{M}, 70 \mu \mathrm{M}, 0.35 \mathrm{mM}$ and $0.70 \mathrm{mM}$. For instance, after one week of growth in the presence of $7 \mu \mathrm{M}$ and $0.7 \mathrm{mM}$, the number of viable cells decreased by 30 and $50 \%$, respectively, compared to control. A similar effect was also seen with other cancer cell lines tested, which include HaCaT (human keratinocyte derived tumor-like cells) and A549 (human lung adenocarcinoma cells) ( $\odot$ Table 2 ). In the mechanistic studies with $\mathrm{HaCaT}$ and A549 cells, apoptosis-specific DNA fragmentation was observed within $48 \mathrm{~h}$ after the addition of $1.4 \mathrm{mM} \mathrm{APP} \mathrm{[9].}$ One of the specific features of APP is its selective inhibition of fast dividing cancer cells with apparently no influence on cells with a slower growth rate (normal cells). This has been demonstrated with HaCaT cells, which behave like tumor cells in the presence of $10 \%$ fetal calf serum (FCS) and like normal cells at $1 \%$ FCS or lower. While APP at $1.4 \mathrm{mM}$ induced within $48 \mathrm{~h}$ about $30 \%$ of cell death of HaCaT cells growing rapidly in 10\% FCS (๑ Table 2), almost no cell death was observed when they were grown in $1 \%$ FCS [9].

The mechanism of action of APP was investigated using flow cytometry. These studies suggest that APP interferes with the $\mathrm{S}$ period of the cell cycle, i.e., the DNA synthesis period. APP inhibited the transition of cells from the $S$ period to the G2/M period ( Fig.3), and consequently induced cell death. For HeLa cells which grow rapidly in the presence of $10 \%$ FCS, a significant increase in $S$ period cell population and decrease in $\mathrm{G} 2 / \mathrm{M}$ period cell population was observed $24 \mathrm{~h}$ after the addition of APP (1.4 mM), with about $10 \%$ of cell death occurring in $48 \mathrm{~h}$ ( Table 2) [9]. APP shows a good synergistic effect with known anticancer drugs such as cisplatin. As shown in Table 2, APP showed cidal effects on monocytic leukemia cells (THP-1 cells) as observed after $48 \mathrm{~h}$ incubation. In another experimental setup with THP-1 after $48 \mathrm{~h}$ incubation, the cell mortality was between $46 \%$ and $57 \%$ in the presence of $0.3,0.7$ or $1.4 \mathrm{mM}$ of APP and $40 \%$ for $2 \mathrm{mM}$ of cisplatin alone. APP $(0.3,0.7$ or $1.4 \mathrm{mM})$ combined with cisplatin $(2 \mathrm{mM})$ increased the cell mortality up $83 \%$ to $90 \%$ [9].

The anticancer effect of APP has also been demonstrated in C57 BL/6 mice [9]. B16 melanoma cells $\left(5 \times 10^{6}\right.$ cells) were disseminated in the abdominal cavities of the mice, PBS or APP solution $(200 \mathrm{mg} / \mathrm{kg}$ ) was administered into the abdominal cavities every day from day 15, and the survival was examined. The average survival time for mice after administration was 8 days for those receiving APP and 4 for those given only PBS. APP also inhibited tumor growth and the migration of the tumor cells in mice when APP was subcutaneously injected into tumor spots at a dosage of $25 \mathrm{mg} / \mathrm{kg}$ daily ( Fig. 2) [9].

Further work with APP could involve testing its toxicity and elucidating the molecular mechanism of action, for example, whether APP interferes with DNA synthesis by interfering with DNA polymerase (EC 2.7.7.6, EC 2.7.7.7). APP has been reported to be an antibacterial, which may be used for food preservation [51]. The antibacterial effect of APP might also be related to its inhibition on DNA synthesis. APP has been documented as a good water-soluble antioxidant due to the existence of a conjugated enolone function in the molecule ( $\bullet$ Fig. 1) [42].

For microthecin, its anticancer effect was examined using malignant blood cell lines (Mutu, Ramos, Raji) and the nonmalignant immortalized lymphoblastoid cell line [52]. Microthecin was toxic to all the cell lines tested with a cell mortality of $85-95 \%$ at $50 \mathrm{ppm}(0.347 \mathrm{mM})$ [52]. The high efficacy of microthecin as a cell toxin could make it a promising drug lead. Since the nonmalignant immortalized lymphoblastoid cell line was also killed at low microthecin concentrations, there is obviously a need for a microthecin delivery system such as a carrier to transport it in inactive form to cancer tissues where it could be activated to its effective form. Reductive activation of cancer drugs has been reported, as one based on lower oxygen pressure in cancer tissues compared to normal tissues (tumor hypoxia) [53].

\section{The antimicrobial effects of the AF \\ derivative microthecin}

Microthecin as an antibacterial agent exhibits inhibitory activities against both gram-positive and gram-negative bacteria, including the human pathogen Pseudomonas aeruginosa PAO1 at 200-2000 ppm [52]. These studies also showed that microthecin was more efficient in controlling the growth of $P$. aeruginosa under anaerobic conditions. Microthecin also shows activity against Aphanomyces cochlioides, an oomycete plant pathogen causing root rot disease [54]. It would be interesting to explore the efficacy of microthecin against other oomycete species that cause diseases in humans and livestocks.

The antimicrobial and cytotoxic mechanisms of action of microthecin remain unknown. It has been assumed that the $\alpha, \beta$ unsaturated ketone structure which exists in both microthecin and APP ( Fig. 1) is essential for their bioactivities [55].

In summary, AF, APP and microthecin and their derivatives might be selected as new leads for anticancer drug development to meet the low efficiency and increasing problem of resistance of current cancer drugs. Further work is needed to consolidate these in vitro and in vivo results achieved and evaluate the possible toxicity and efficacy of these compounds against existing therapies before tests in human volunteers can begin. The other AF derivatives, naturally occurring 1,5-anhydro-D-mannitol, 1-deoxymannojirimycin, haliclonol, 5-epipentenomycin I, bissetone, palythazine, isopalythazine, and clavulazine, or the chemically synthesized ones [23] remain to be further evaluated for their biological activity and possible health benefit. 


\section{Acknowledgements}

$\nabla$

The authors are thankful to Dr. Roopa Ghirnikar, senior scientific writer of Danisco U.S. Corporation and Prof. Inge Lundt, Technical University of Denmark, for their critical reading of the current work.

\section{Affiliations}

${ }^{1}$ Department of Medicine, Unit of Emergency Medicine, Karolinska Institute, Huddinge, Stockholm, Sweden

2 Taikai Clinic, Chugo Satsuma-Sendai, Japan

${ }^{3}$ Department of Functional Biology and Pharmacology, Kagoshima University, Sakuragaoka, Kagoshima, Japan

${ }^{4}$ R \& D Division, Nihon Denpun, Ltd. Kagoshima, Japan

${ }^{5}$ Department of Bioscience and Technology, Faculty of Agriculture, Kagoshima University, Kagoshima, Japan

${ }^{6}$ Laboratory of Biorenew and Applied Enzymology, Qingdao Agricultural University, Qingdao, China

${ }^{7}$ Enzyme R \& D, Genencor Division, Danisco A/S, Aarhus, Denmark

\section{References}

1 Drew DP, Krichau N, Reichwald K, Simonsen HT. Guaianolides in apiaceae: perspectives on pharmacology and biosynthesis. Phytochem Rev 2009; 8: 581-599

$2 \mathrm{Yu}$ S, Fiskesund $\mathrm{R}$. The anhydrofructose pathway and its possible role in stress response and signaling. Biochim Biophys Acta 2006; 1760: 1314-1322

$3 \mathrm{Yu}$ S. The anhydrofructose pathway. IUBMB Life 2008; 60: 798-809

$4 \mathrm{Yu}$ S. $\alpha-1,4-$ Glucan lyase, a new starch processing enzyme for production of 1,5-anhydro-D-fructose. Zuckerindustrie 2004; 129: 26-30

$5 \mathrm{Yu}$ S, Andreassen M, Lundt I. Enzymatic production of microthecin by aldos-2-ulose dehydratase from 1,5-anhydro-D-fructose and stability studies of microthecin. Biocatal Biotransformation 2008; 26: 169-176

6 Yoshinaga K, Wakamatsu C, Saeki Y, Abe JI, Hizukuri S. Conversion of 1,5-anhydro-D-fructose into functional compound, ascopyrone $\mathrm{P}$ by heating. J Appl Glycosci 2005; 52: 287-291

7 Hisaku (Hizukuri) S, Takeda Y, Abe JI, Muroya T, Yoshinaga K, Fujisue M. Agent for suppressing or inhibiting bacterial proliferation containing 1,5-anhydro-D-fructose. Jap Patent Appl JP11-266336; 1999

8 Hisaku (Hizukuri) S, Fujisue M, Abe JI. Prophylactic for tooth disease and method for producing food containing the same. Jap Patent Appl JP2004123604; 2004

9 Abeyama K, Yoshimoto Y. Antitumor agent. Eur Patent Appl EP1686122; 2006

10 Deffieux G, Baute R, Baute MA, Atfani M, Carpy A. 1,5-Anhydro-D-fructose, the precursor of the pyrone microthecin in Morchella vulgaris. Phytochemistry 1987; 26: 1391-1393

11 Yu S, Kenne L, Pedersén M. $\alpha$-1,4-Glucan lyase, a new class of starch/glycogen degrading enzyme. I. Efficient purification and characterization from red seaweeds. Biochim Biophys Acta 1993; 1156: 313-320

12 Yu S, Christensen TMIE, Kragh KM, Bojsen K, Marcussen J. Efficient purification, characterization and partial amino acid sequencing of two $\alpha$-1,4-glucan lyases from fungi. Biochim Biophys Acta 1997; 1339: $311-320$

13 Baute MA, Baute R, Deffieux G. Fungal enzymatic activity degrading 1,4$\alpha$-D-glucans to 1,5 -D-anhydrofructose. Phytochemistry 1988; 27 : 3401-3403

14 Baute MA, Deffieux G, Vercauteren J, Baute R, Badoc A. Enzymic activity degrading $1,4-\alpha$-glucans to ascopyrones $P$ and $T$ in Pezizales and Tuberales. Phytochemistry 1993; 33: 41-45

15 Suzuki M, Mizuno H, Akanuma Y, Akanuma H. Synthesis of 1,5-anhydro-D-glucitol from glucose in rat hepatoma cells. J Biochem (Tokyo) 1994; 115: 87-92

16 Suzuki M, Kametani S, Uchida K, Akanuma H. Production of 1,5-anhydroglucitol from 1,5-anhydrofructose in erythroleukemia cells. Eur J Biochem 1996; 240: 23-29

17 Kametani S, Shiga Y, Akanuma H. Hepatic production of 1,5-anhydrofructose and 1,5-anhydroglucitol in rat by the third glycogenolytic pathway. Eur J Biochem 1996; 242: 832-838

18 Shiga Y, Kametani S, Kadokura T, Akanuma H. 1,5-Anhydroglucitol promotes glycogenolysis in Escherichia coli. J Biochem (Tokyo) 1999; 125: $166-172$
19 Broberg A, Kenne L, Pedersén M. Analysis of 1,5-anhydro-D-fructose, microthecin, and 4-deoxy-glycero-hexo-2,3-diulose in algae using gas chromatography-mass spectrometry in selected ion monitoring mode. Anal Biochem 1999: 268: 35-42

20 Andersen SM, Lundt I, Marcussen J, Yu S. 1,5-Anhydro-D-fructose, a versatile chiral building block: biochemistry and chemistry. Carbohydr Res 2002; 337: 873-890

$21 \mathrm{Yu}$ S, Marcussen J. $\alpha-1,4$-Glucan lyase, molecular features and its use for production of 1,5-anhydro-D-fructose from starch. In: Gilbert HJ, Davies GJ, Henrissat B, Svensson B, editors. Recent advances in carbohydrate bioengineering. London: Royal Society of Chemistry (RS.C) Press; 1999: 243-250

22 Dekany G, Lundt I, Niedermair F, Bichler S, Spreitz J, Sprenger FK, Stütz AE. 1,5-Anhydro-D-fructose from D-fructose. Carbohydr Res 2007; 342: $1249-1253$

23 Lundt I, Yu S. 1,5-Anhydro-D-fructose: biocatalytic and chemical synthetic methods for the preparation, transformation and derivatization. Carbohydr Res 2010; 345: 181-190

24 Andersen SM, Jensen HM, Yu S. Ascopyrone P: chemical synthesis from D-glucose. J Carbohydr Chem 2002; 21: 569-578

25 Kühn A, Yu S, Giffhorn F. Catabolism of 1,5-anhydro-D-fructose in Sinorhizobium morelense S-30.7.5: discovery, characterization, and overexpression of a new 1,5-anhydro-D-fructose reductase and its application in sugar analysis and rare sugar synthesis. Appl Environ Microbiol 2006; 72: 1248-1257

26 Andersen SM, Lundt I, Marcussen J. 1,5-Anhydro-D-fructose: stereoselective conversions to 1,5-anhydroalditols and deoxy/amino substituted analogues. J Carbohydr Chem 2000; 19: 717-725

27 Maier P, Andersen SM, Lundt I. 1,5-Anhydro-D-fructose as a chiral building block: a novel approach to 1-deoxymannojirimycin. Synthesis 2006; 827-830

28 Deffieux G, Vercauterena J, Baute MA, Neveu A, Baute R. Bacterial conversion of the fungal ascopyrone $\mathrm{T}$ to $2(S)$-dihydroascopyrone $\mathrm{T}$ (haliclonol). Phytochemistry 1994; 36: 849-852

29 Baute MA, Deffieux G, Baute R, Badoc A, Vercauteren J, Léger JM, Neveu A. Fungal enzymic activity degrading $1,4-\alpha$-D-glucans to echinosporin (5epipentenomycin I). Phytochemistry 1991; 30: 1419-1423

30 Brehm M, Göckel VH, Jarglis P, Lichtenthaler FW. Expedient conversion of D-glucose into 1,5-anhydro-D-fructose and into single stereogeniccenter dihydropyranones, suitable six-carbon scaffolds for concise syntheses of the soft-coral constituents (-)-bissetone and (-)-palythazine. Tetrahedron Asym 2008; 19: 358-373

31 Cardellina JH, Hendrickson RL, Manfredi KP, Strobel SA, Clardy J. Bissetone, a unique antimicrobial pyranone from the gorgonian Briareu polyanthes. Tetrahedron Lett 1987; 28 : 727-730

32 Taguchi T, Haruna M, Okuda J. Effects of 1,5-anhydro-D-fructose on selected glucose-metabolizing enzymes. Biotechnol Appl Biochem 1993; 18: $275-283$

33 Ferrari RA, Mandelstam P, Crane RK. 1,5-Anhydro-D-glucitol 6-phosphate and its use for the specific inhibition of the hexokinase reaction in tissue homogenates. Arch Biochem Biophys 1959; 80: 372-377

34 Keston AS. Mutarotase inhibition by L-deoxyglucose. Science 1964; 143: 698-700

35 Carabaza A, Ciudad CJ, Baqué S, Guinovart JJ. Glucose has to be phosphorylated to activate glycogen synthase, but not to inactivate glycogen phosphorylase in hepatocytes. FEBS Lett 1992; 296: 211-214

36 Yamanouchi T, Inoue T, Ichiyanagi K, Sakai T, Ogata N. 1,5-Anhydroglucitol stimulates insulin release in insulinoma cell lines. Biochim Biophys Acta 2003; 1623: 82-87

37 Yamanouchi T, Ogata N, Yoshimura T, Inoue T, Ogata E, Kawasaki T, Kashiwabara A, Muraoka H. Transport of 1,5-anhydro-D-glucitol into insulinoma cells by a glucose-sensitive transport system. Biochim Biophys Acta 2000; 1474: 291-298

38 Abeyama $K$, Yoshimoto Y, Nagayama S. Adiponectin production promoting agent. Jap Patent Appl JP2008195630; 2008

39 Yamanouchi T, Tachibana Y, Akanuma H, Minoda S, Shinohara T, Moromizato H, Miyashita H, Akaoka I. Origin and disposal of 1,5-anhydroglucitol, a major polyol in the human body. Am J Physiol 1992; 263: E268E273

40 Yabuuchi M, Masuda M, Katoh K, Nakamura T, Akanuma H. Simple enzymatic method for determining 1,5-anhydro-D-glucitol in plasma for diagnosis of diabetes mellitus. Clin Chem 1989; 35: 2039-2043 
41 Yamaji K, Sarker KP, Maruyama I, Hizukuri S. Antioxidant effects of 1,5anhydro-D-fructose, a new natural sugar, in vitro. Planta Med 2002; 68 : 16-19

42 Yuan YB, Cao R, Westh B, Yu S. Examination of 1,5-anhydro-D-fructose and the enolone ascopyrone $P$, metabolites of the anhydrofructose pathway of glycogen and starch degradation, for their possible application in fruits, vegetables and beverages as antibrowning agents. J Agric Food Chem 2005; 53: 9491-9497

$43 \mathrm{Yu}$ S, Pedersén M, Kenne L. Glucan lyase producing 1,5-anhydrofructose. US Patent Appl US5695970; 1997

44 Yajima M, Furuhashi S, Muroya T, Yoshinaga K, Fujisue M. Method for preventing discoloration of noodle and noodle quality improver. Jap Patent Appl JP 2003047416; 2003

45 Lee O, Bruce WR, Dong Q Bruce J, Mehta R, O'Brien PJ. Fructose and carbonyl metabolites as endogenous toxins. Chem Biol Interact 2009; 178: 332-339

46 Abeyama K, Maruyama Y, Yoshimoto Y, Yoshinaga K. Anti-inflammatory agent. Jap Patent Appl JP2006306814; 2006

47 Meng XJ, Kawahara KI, Nawa Y, Miura N, Shrestha B, Tancharoen S, Sameshima H, Hashiguchi T, Maruyama I. 1,5-Anhydro-D-fructose attenuates lipopolysaccharide-induced cytokine release via suppression of NF-кB p 65 phosphorylation. Biochem Biophys Res Commun 2009; 380: $343-348$

48 Meng XJ, Kawahara KI, Matsushita K, Nawa Y, Shrestha B, Kikuchi K, Sameshima H, Hashiguchi T, Maruyama I. Attenuation of LPS-induced iNOS expression by 1,5-anhydro-D-fructose. Biochem Biophys Res Commun 2009; 387: 42-46

$49 \mathrm{Yu}$ S, Mei J, Ahrén B. Basic toxicology and metabolism studies of 1,5-anhydro-D-fructose using bacteria, cultured mammalian cells and rodent models. Food Chem Toxicol 2004; 42: 1677-1686

50 Mei J, Yu S, Ahrén B. A 90-day toxicological evaluation of 1,5-anhydroD-fructose in Sprague-Dawley rats. Drug Chem Toxicol 2005; 28: 263 272
51 Thomas $L V$, Ingram RE, Yu S, Delves-Broughton J. Investigation of the effectiveness of ascopyrone P as a food preservative. Int J Food Microbiol 2004; 93: 319-323

52 Fiskesund R, Thomas LV, Schobert M, Ernberg I, Lundt I, Yu S. Inhibition spectrum studies of microthecin and other anhydrofructose derivatives using selected strains of gram-positive and -negative bacteria, yeasts and moulds, and investigation of the cytotoxicity of microthecin to malignant blood cell lines. J Appl Microbiol 2009; 106: 624-633

53 Brown JM, Wilson WR. Exploiting tumour hypoxia in cancer treatment. Nat Rev Cancer 2004; 4: 437-447

54 Morgan AJ, Turner M, Yu S, Weiergang I, Pedersen HC. Antimicrobial formulation comprising microthecin or derivatives thereof and their uses in prevention and therapy. Int Patent Appl WO2004083226; 2004

55 Merlet D, Mellado M, Deffieux G, Baute MA, Cambar J. Cytotoxic effect of biogenetically related pyrone and cyclopentenone fungal metabolites on renal cell line (LLC-PK1). Bull Soc Pharm Bordeaux 1991; 130: 5-16

56 Bojsen $\mathrm{K}, \mathrm{Yu} \mathrm{S}$, Kragh KM, Marcussen J. A group of $\alpha-1,4$-glucan lyases and their genes from the red alga Gracilariopsis lemaneiformis: purification, cloning, and heterologous expression. Biochim Biophys Acta 1999; 1430: 396-402

57 Yoshinaga K, Fujisue M, Abe JI, Hanashiro I, Takeda Y, Muroya K, Hizukuri $S$. Characterization of exo- $(1,4)-\alpha$ glucan lyase from red alga Gracilaria chorda. Activation, inactivation and the kinetic properties of the enzyme. Biochim Biophys Acta 1999; 1472: 447-454

58 Bojsen $K, Y u$ S, Marcussen J. A family of $\alpha$-1,4-glucan lyase genes from fungi. Cloning, complete sequencing, and heterologous expression. Plant Mol Biol 1999; 40: 445-454

59 Yu S, Refdahl C, Lundt I. Enzymatic description of the anhydrofructose pathway of glycogen degradation. I. Identification and purification of anhydrofructose dehydratase, ascopyrone tautomerase and $\alpha-1,4$-glucan lyase in the fungus Anthracobia melaloma. Biochim Biophys Acta 2004; 1672: 120-129 